\title{
Comparison of somatic characteristics and motion prerequisites between children who perform organized physical activities, and children not engaged in sports
}

\author{
K. Svatora a, ${ }^{*} \mathbb{D}$, P. Spottova a ${ }^{(\mathbb{D}), T \text {. Fajfrlikova a }}$ \\ a Center of Physical Education and Sport, Faculty of Education, University of West Bohemia, Czechia. \\ *Corresponding author Tel: +420 377636 403; Email: ksvatora@ktv.zcu.cz \\ DOI: https://doi.orq/10.34256/ijpefs2042 \\ Received: 08-09-2020, Revised: 05-10-2020; Accepted: 10-10-2020; Published: 12-10-2020
}

Abstract: Low physical activity in children of pre-school and younger school age has been a multifaceted problem for several years, which is being addressed by several scientists, primarily doctors, educationalists, and psychologists. The purpose of our study is to compare somatic and motion prerequisites among physically active and physically inactive children from the first grades of primary schools in the Pilsen region. The research sample consisted of 753 pupils from the first grades of primary schools in the Pilsen region, of which 421 boys and 332 girls. Of a total number of pupils, 176 (23.4\%) girls and 275 (36.5\%) boys are engaged in any sporting activities. At the time of measurement, their average age was $6.87 \pm 0.59$ years. To obtain somatic characteristics, body heights and weights of children were measured, and from the measured data, a body mass index (BMI) for the child category was calculated. To determine the level of motion prerequisites, we used the DMT 6-18 test battery, consisting of 8 tests. The tests are aim to assess the level of dynamic and explosive power, speed, coordination, balance, flexibility, and endurance. The results of our study highlight the fact that even in the age range of 6 to 7 years, there are significant differences between physically active and physically inactive children in the tests, which monitor motion prerequisites of children. Statistically significant differences were seen primarily in tests which monitor the level of fitness abilities, i.e. the components of the body health-oriented fitness.

Keywords: BMI index, Motion assumptions, Younger school age, DMT test battery

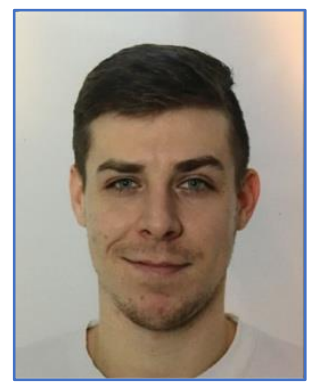

Mgr. Karel Švátora is an Assistant Professor at the Faculty of Education of the University of West Bohemia in Pilsen. He works there in the Center of Physical Education and Sport. At the same time, he studies Ph.D. in Kinanthropology at the Faculty of Physical Education and Sport of the Charles University in Prague. His research field is the monitoring of physical activity, sport psychology, motor control and learning.

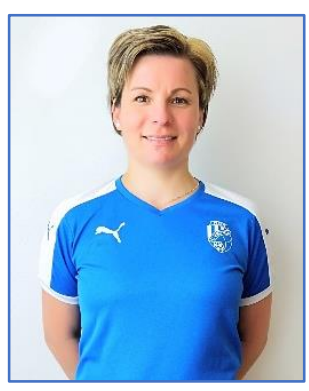

Mgr. Petra Špottová, Ph.D., is an Assistant Professor at the Faculty of Education of the University of West Bohemia in Pilsen since 2006. She has many years of experience in gymnastics and its application in sports training of other sports. Within the faculty, she participates in projects aimed at the didactics of physical education, reflection and evaluation of teaching.

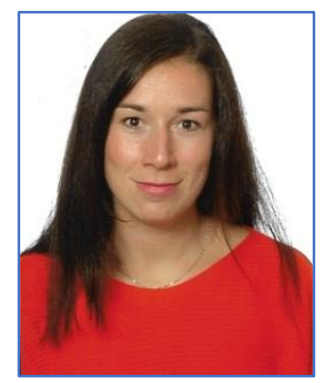

Mgr. Tereza Fajfrlíková is an Assistant Professor at the University of West Bohemia in Pilsen. She works in the Center for Physical Education and Sport. She conducts professional seminars for future kindergarten teachers. She is also part of a project that deals with physical activities for preschool children. She has been leading physical exercise for children from the age of 4 to 6 for 10 years. 


\section{Introduction}

During phylogenesis, the human body was developed in movement and to movement. Within a relatively short period of time, the proportion of physical activity in humans was rapidly decreased, and, in some individuals, physical activity even disappeared from their daily routine. This problem seems to be more serious if this involves the physical inactivity of children. The level of physical activity among young people is decreased in countries all around the world, especially in poor urban areas [1]. According to the research performed by Mužík [2] and Sigmund [3], the physical activity of children at the first level of primary schools is significantly decreased after admission to the first level of school education. Mužík [2] states that sedentary lifestyle predominates among younger school age children, and physical activity of these children includes only $12 \%$ of their daytime on average, and school movement activities represent only $1 \%$. This decrease is largely caused by increasingly frequent sedentary manners of leisure time spending. For example, fewer children walk to and from school, they spend too much time on passive entertainment, such as watching TV, playing computer games, and other IT technologies - often at the expense of time and opportunities for physical activities and sports. Due to sedentary school activities, the proportion of time devoted to school physical education and other school physical activities is also decreasing [4-6]. Today, a number of studies highlight the importance of proper motor development of children for their future $[7,8]$, and also preventive and therapeutic effects of adequate physical activities. At their later ages, inactive children exhibit more frequent occurrence of cardiovascular diseases, including their risk factors, such as hypertension, overweight, and obesity [9, 10]. In addition, Kuntsche [11] links, between other aspects, the level of physical fitness, quality of life, and well-being. The psychosocial benefit acquired in the course of the motor learning process is another positive aspect of physical activity in childhood. Learning movement skills within the framework of spontaneous and organized physical activity improves the physical performance of children [12-15], emotional development [16], and social interactions $[17,18]$. Further studies point out the relationship between learning disabilities and the development of motor skills. In addition, there are indications that motor learning can have an impact on language development in children [19].
According to $[1]$, to ensure healthy development of children and young people in the age range of 5 to 17 years, they should have at least 60 minutes of physical activity, performed at medium to high intensity every day. Patterns of movement regimen and healthy lifestyle acquired in childhood and adolescence will likely be maintained throughout their lifetime $[1,20]$. The level of physical fitness of people is directly connected with health. This relationship is strengthened with age [21].

For these reasons, the concept of healthoriented physical prowess (fitness) was introduced in the past. According to [21], this relates to fitness affecting the health condition and have preventive effects on health problems arising as a result of physical inactivity, hypokinesia. Corresponding motor performance requires the implementation of appropriate motion stimuli, which are based on spontaneous physical activities already in the early stages of life, and they gradually move into organized physical activities. Undoubtedly, the family environment has a decisive influence on the health of children and their physical and mental development [22-24]. The dependence of physical health on the socioeconomic status of the family is mentioned by Moor et al., [25].

The goal of our research is to highlight the existence of differences in somatic characteristics, and significant differences in the physical fitness of children already at the youngest school age (six to seven years old). Our study compares basic somatic characteristics (height, weight), aerobic fitness, muscle fitness, coordination, balance, and flexibility of children from the first grades of primary schools, who are engaged in organized physical activities in their leisure time, and children who do not attend any physical training hobby groups.

\section{Methods}

\subsection{1 Methods for detecting somatic characteristics}

Before commencing the test, weights and heights of children were measured using calibrated instruments. The height is given in metres, rounded to two decimal places. The weight is given in kilograms, rounded to one decimal place. The BMI was determined using a BMI calculator for childhood. According to the BMI percentile in the population of children of a given age group, we identified a group of underweight children (under the 10th percentile), 
normal weight children (between 10th and 90th percentile), overweight children (90th and 97th percentile), and obese children (over 90 th percentile].

\subsection{Methods for detecting movement performance}

To determine the level of movement performance, we used a DMT 6-18 test battery [21] consisting of eight tests. On the basis of the test results, we can determine the level of motion prerequisites, which are the indicators of movement abilities, most of which relate to physical fitness of the individual, as well as health-oriented fitness.

\section{Brief description of the tests:}

Test No. 1: 20-metre sprint - after starting command, probands run out in pairs from a semi-high starting position (ready, steady, go - hands clapping or wooden rattle clicking). The time is rounded to one decimal place. This test consists of two retests. From the results of this test, speed of action and reaction are determined.

Test No. 2: Balancing backwards - probands are called to go backwards 8 steps on a special low balance beam. We counted the number of steps performed by the pupils without touching the pad. The balance beams are made of wood, available in three widths $(6 \mathrm{~cm}, 4.5 \mathrm{~cm}$, and $3 \mathrm{~cm})$, and put on the floor. Pupils have two attempts on the balance beams of all widths. We counted the total number of the steps performed on all three widths of the balance beams. From the results of this test, balance ability and movement co-ordination are determined.

Test No. 3: Jumping sideways with legs together forwards and backwards - this test was also performed on a special wooden pad, partitioned with a wooden slat in the middle. The probands are called to jump sideways with legs together from one half of the pad to the other for a duration of 15 seconds. This test is repeated twice. From the results of this test, we can estimate the level of movement co-ordination, action speed, and dynamic strength of the lower extremities.

Test No. 4: Modified push-ups - probands are called to perform repeatedly a modified push-up, which starts from a laying position on the stomach with the hands behind back, followed by a transition to the push-up position, one hand is put on the back of the other hand, and probands return to the stomach position and starting position. The person checking the correct execution of this test counts only attempts when the hips are not deflected during this exercise. The number of correctly performed push-ups in 40 seconds is counted. From the results of this test, we can estimate the dynamic strength of the upper extremities.

Test No. 5: Sit-ups - the basic position is a lying position with the bent legs and hands placed over the back of the head. Probands perform repeatedly sit-ups for a duration of 40 seconds. The person checking the correct execution of this test fixes the probands' legs to the mat. The probands are called to raise their torso to a perpendicular position, without putting of their pelvis from the mat at the initial stage. Every correctly performed attempt is counted. From the results of this test, we can estimate the strength abilities of abdominal muscles.

Test No. 6: Stand and reach - probands stand on a special stool equipped with a measuring instrument in its front part, and perform a deep forward bend, trying to touch the measuring instrument. Finally, the bend depth is read on the instrument. From the results of this test, we can estimate the flexibility of the torso and the back side of the lower extremities.

Test No. 7: Standing long jump - probands are prepared behind the line and, and with a massive bounce, they try to jump with legs together as far as possible. Performance is measured in centimetres, rounded to whole numbers. This test is repeated twice. From the results of this test, we can estimate the level of explosive power of the lower extremities.

Test No. 8: Six-minute run - probands are called to run/walk as long as possible distance within six minutes. The children are called to run around the cones located in the corners of a volleyball court.

The number of rounds around the entire volleyball court are counted to each proband by the persons checking the proper execution of this task. After elapsing the time, the pupils will stop at the place they reached. Depending on a distance reached by the probands, we add an estimated number of metres to the total number of rounds, multiplied by 54 . From the results of this test, we can estimate the level of general endurance.

\subsection{Statistical data processing}

The measured data were processed using the software called STATISTICA 6.0. For preliminary analysis and to determine dependence between the variables, the correlation analysis, using Spearman's correlation co-efficient, was used. The values of the 
correlation co-efficient at an interval of $0.1 \geq r \geq 0.29$ are considered the indicator of low to medium correlation, $0.3 \geq r \geq 0.49$ the indicator of medium to substantial correlation, and $>0.49$ is considered the indicator of very strong, substantial correlation [27]. To determine statistical differences between the groups in individual tests, the t-test for two independent selections was used. The statistical significance level was set at: $a \geq 0.05$. To determine the substantive significance of intergroup differences, the calculation of Cohen $d$ was used [28].

\subsection{Description of the research sample}

The research sample consisted of 753 pupils from the first classes of primary schools in the Pilsen Region (Pilsen and Rokycany), of which 421 boys and 332 girls. All pupils had to answer the question whether they attend any physical training hobby group in their free time, and how many times a week they are engaged in organised physical activities. If children do sport activities in this manner at least twice a week, they were assigned to a group called preliminary "athletes", and if such activities were performed irregularly and repeated only once a week, or if none activity was reported, such pupils were placed in the group called "non-athletes". Out of the total number of these pupils, $176(23.4 \%$ of the entire sample) girls, resp. 275 (36.5\% of the entire sample) boys are engaged in sports. Testing was carried out always in the springs of 2016 to 2018. At the time of measurement, the average age of the children was $6.87 \pm 0.59$ years.

\subsection{Description of the variables}

For ease of reference, we specify the list of variables in our results, including the reported units of measurement:

Body height [metre, m], Body weight [kilogram, kg], and BMI $\left[\mathrm{kg} / \mathrm{m}^{2}\right]$ represent somatic characteristics.

SPRINT_1 and SPRINT_2 represent the first and second attempts performed in the 20-metre run test [second, s].

BAL_SUM - the total number of steps performed in two retests on the balance beams with the widths of $6 \mathrm{~cm}$, $4.5 \mathrm{~cm}$, and $3 \mathrm{~cm}$. The maximum possible number of steps performed in this test was $6 \times 8$ steps $=48$.

JUMP_1 and JUMP_2 is the number of jumping sideways performed in the first and second attempts of the jumping sideways with legs together test.
STAND_REACH is the value achieved in the stand and reach test. The positive $(+)$ values represent the reach below the zero value of the special elevated pad, while the negative (-) values represent the distance above the zero value [centimetre, $\mathrm{cm}$ ].

PUSH-UPS and SIT-UPS are given in the number of correctly performed and completed exercises.

LONG_J_1 and LONG_J_2 represent the first and second attempts of the standing long jump test [metre, $\mathrm{m}$ ].

6-MIN RUN represents results of the six-minute run test [metre, $\mathrm{m}]$.

\section{Results}

\subsection{Interim analysis}

The fact whether a child is engaged in sports or not is demonstrated with a weak to moderate dependence with performances in both attempts in the tests: 20-metre sprint $\left(r_{1}=0.24, r_{2}=0.25\right)$, jumping sideways $\left(r_{1}=0.18, r_{2}=0.18\right)$, standing long jump $\left(r_{1}=0.27, r_{2}=0.29\right)$, and six-minute run $(r=0.26)$ (Table 2). Mild to moderate dependence was also found in the case of sex and performance variables in the tests: 20 metre sprint $\left(r_{1}=0.24, r 2=0.25\right)$, stand and reach $(r=0.22)$, standing long jump $\left.\left(r_{1}\right)=0.17, r 2=0.18\right)$, and six-minute run $(r=0.27)$ (Table 2$)$.

As regards correlations between the attempts of individual tests and correlations between the individual tests of the DMT6-18 test battery, a very high measure of dependence was found between two attempts of the 20-metre spring $(r=0.67)$, jumping sideways ( $r=0.82)$, and standing long jump ( $r=0.83)$, indicating a high consistency of these tests. Moderate to high dependence $\left(r_{1}=0.36, r_{2}=0,9\right)$ was demonstrated between both attempts in the 20-metre sprint test and both attempts in the jumping sideways tests. A high measure of dependence was ascertained between the 20-metre sprint and standing long jump $(r=0.52)$ tests (Table 2).

\subsection{Comparison of somatic characteristics}

Table 3 and figure 1 show that the largest proportion of children with normal weight $(84.7 \%)$ can be found among physically active boys. Most obese children can be found among physically inactive boys $(10.3 \%)$, while $6.2 \%$ of obese children are among physically active boys. 
Table 1 Overview of means and standard deviations of all variables in the compared groups

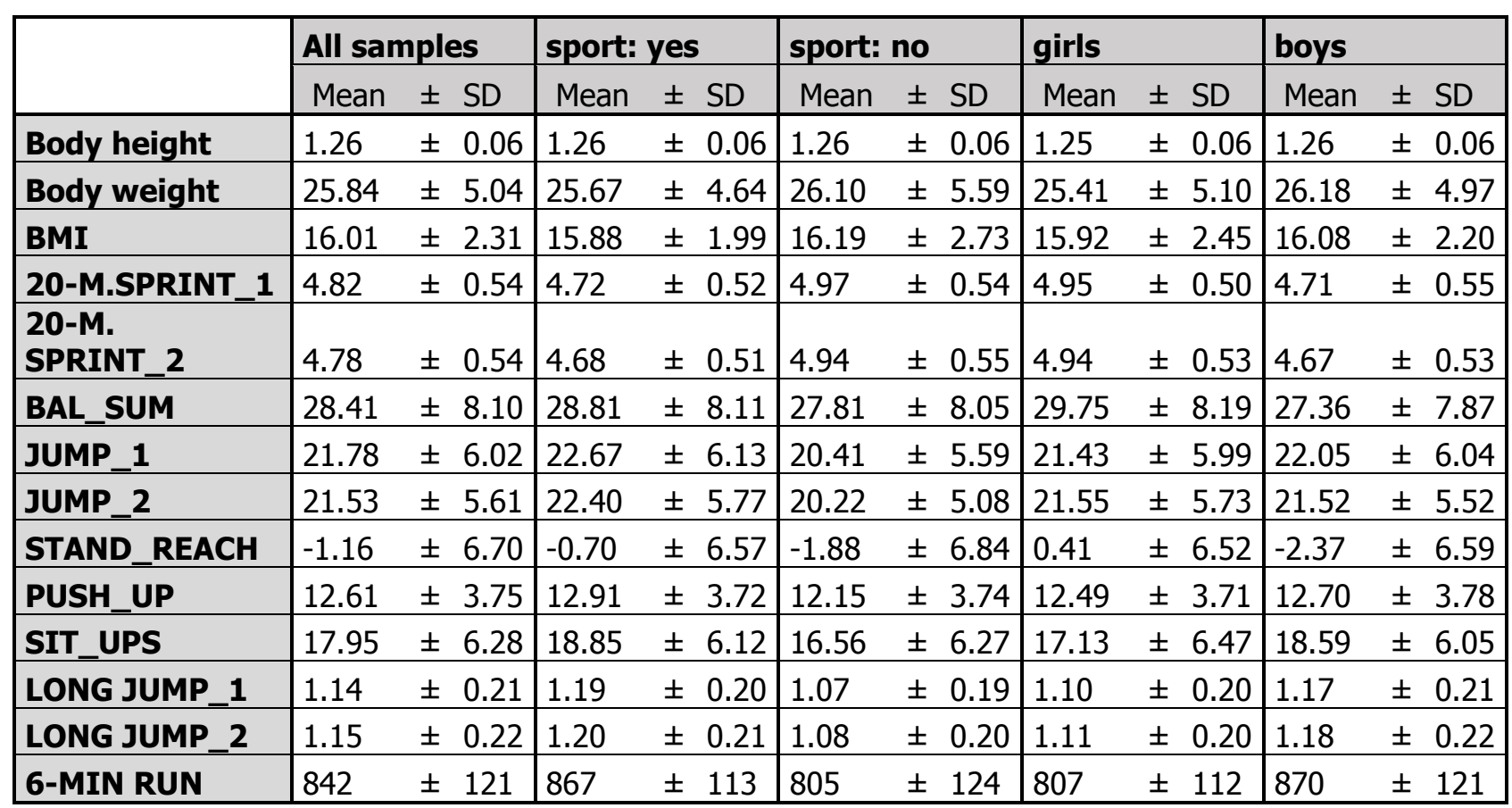

Table 2 Correlation matrix illustrating the measure of dependence of individual variables

\begin{tabular}{|c|c|c|c|c|c|c|c|c|c|c|c|}
\hline & SP_1 & SP_2 & B_S & SK_1 & SK_2 & B_O & CR & UPS & L_J_1 & L_J_2 & 6MIN \\
\hline SPORT & $0.25^{* * *}$ & $-0.24 * * *$ & 0.07 & $0.18^{* * *}$ & $0.18^{* * *}$ & $0.10^{* * *}$ & $0.10 * * *$ & $0.20 * * *$ & $0.27 * * *$ & $0.29 * * *$ & $0.26 * * *$ \\
\hline SEX & \begin{tabular}{|l} 
\\
$0.24 * * *$ \\
\end{tabular} & $-0.25 * * *$ & $\overline{0.14 * * *}$ & 0.04 & -0.01 & $\overline{-}-22 * * *$ & 0.01 & $0.11^{* * *}$ & $0.17 * * *$ & $0.18^{* * *}$ & $0.27 * * *$ \\
\hline BODY HEIGHT & $0.12 * * *$ & $-0.14 * * *$ & $0.11^{* * *}$ & 0.02 & 0.00 & -0.07 & 0.02 & 0.04 & 0.08 & $0.11^{* * *}$ & -0.04 \\
\hline BODY WEIGHT & 0.00 & -0.01 & $0.18^{* * *}$ & -0.06 & -0.07 & -0.04 & -0.03 & -0.05 & -0.05 & -0.03 & $0.14 * * *$ \\
\hline SPRINT_1 & 1.00 & $0.67 *$ & $\begin{array}{l} \\
0.14^{* * *}\end{array}$ & $\begin{array}{l}- \\
0.37 * *\end{array}$ & $\overline{0.39 * *}$ & -0.08 & $\begin{array}{l} \\
0.26 * * *\end{array}$ & $\overline{0.36 * *}$ & $-0.51 *$ & $-0.52 *$ & $\overline{0} \overline{0.32 * *}$ \\
\hline SPRINT_2 & & 1.00 & -0.12 & $\begin{array}{l}\overline{0} \\
0.36 * *\end{array}$ & $\overline{0.36 * *}$ & -0.05 & $\overline{0}-24 * * *$ & $\overline{0.33 * *}$ & $-0.50 *$ & $-0.52 *$ & $\overline{0} \mathbf{0} 1 * *$ \\
\hline BAL_SUM & & & 1.00 & $0.34 * *$ & $0.36 * *$ & $0.12 * * *$ & $0.18^{* * *}$ & $0.20 * * *$ & $0.23 * * *$ & $0.19 * * *$ & $0.16 * * *$ \\
\hline JUMP_1 & & & & 1.00 & $0.82 *$ & $0.15^{* * *}$ & $0.41 * *$ & $0.34 * *$ & $0.45 * *$ & $0.44 * *$ & $0.22 * * *$ \\
\hline JUMP_2 & & & & & 1.00 & $0.15^{* * *}$ & $0.44 * *$ & $0.35 * *$ & $0.45 * *$ & $0.41 * *$ & $0.25 * * *$ \\
\hline STAND_REACH & & & & & & 1.00 & $0.10^{* * *}$ & $0.11^{* * *}$ & $0.12 * * *$ & $0.14^{* * *}$ & 0.08 \\
\hline PUSH_UP & & & & & & & 1.00 & $0.38 * *$ & $0.27 * * *$ & $0.23 * * *$ & $0.13 * * *$ \\
\hline SIT_UPS & & & & & & & & 1.00 & $0.36 * *$ & $0.33 * *$ & $0.19 * * *$ \\
\hline LONG_J_1 & & & & & & & & & 1.00 & $0.83 *$ & $0.35 * *$ \\
\hline LONG_J_2 & & & & & & & & & & 1.00 & $0.39 * *$ \\
\hline 6-MIN RUN & & & & & & & & & & & 1.00 \\
\hline
\end{tabular}

* Strong dependence between variables, $* *$ moderate dependence between variables, $* * *$ weak dependence between variables 
In the group of physically active girls, the same percentage of obese (6.2\%) appears as in boys. In the group of physically inactive girls, we found $7.7 \%$ of obese girls.

Only $3.6 \%$ physically active boys, respectively $6.8 \%$ of girls, were overweight. In the group of physically inactive children, $7.5 \%$ of boys, respectively $7.7 \%$ of girls, were overweight. As regards the number of children with a low weight, more underweight children are among the girls, the least underweight children are among physically active boys.

Reference data from 2001 foresee $6.6 \%$ of obese children in the group of children between 6 to 10.99 years old [26].
We can therefore say that among physically active girls and boys from our sample, the prevalence of obese children is slightly lower than the reference value, while the percentage of obese children is higher in the group of physically inactive children. The reference value of the occurrence of overweight children is $8.9 \%$. In the group of physically active and physically inactive children, the percentage of overweight children is below the reference value. For our age group, the reference value of underweight children is $8.1 \%$. This reference value is slightly exceeded in all groups of our sample. However, in our sample, only 6 children $(0.8 \%)$ of the total number had BMI below the third percentile. As regards the statistical comparison of BMI between physically active and physically inactive children, no significant differences were found.

Table 3 Absolute frequency of physically active and physically inactive girls and and boys with underweight, normal weight, overweight, and obesity.

\begin{tabular}{|l|l|l|l|l|}
\hline \multirow{2}{*}{$\mathbf{N}=\mathbf{7 5 3}$} & \multicolumn{2}{|l|}{ Sport: yes } & \multicolumn{2}{l|}{ Sport: no } \\
\cline { 2 - 5 } & Girls & Boys & Girls & Boys \\
\hline Underweight & 18 & 15 & 14 & 13 \\
\hline Normal weight & 135 & 233 & 118 & 107 \\
\hline Overweight & 12 & 10 & 12 & 11 \\
\hline Obesity & 11 & 17 & 12 & 15 \\
\hline
\end{tabular}

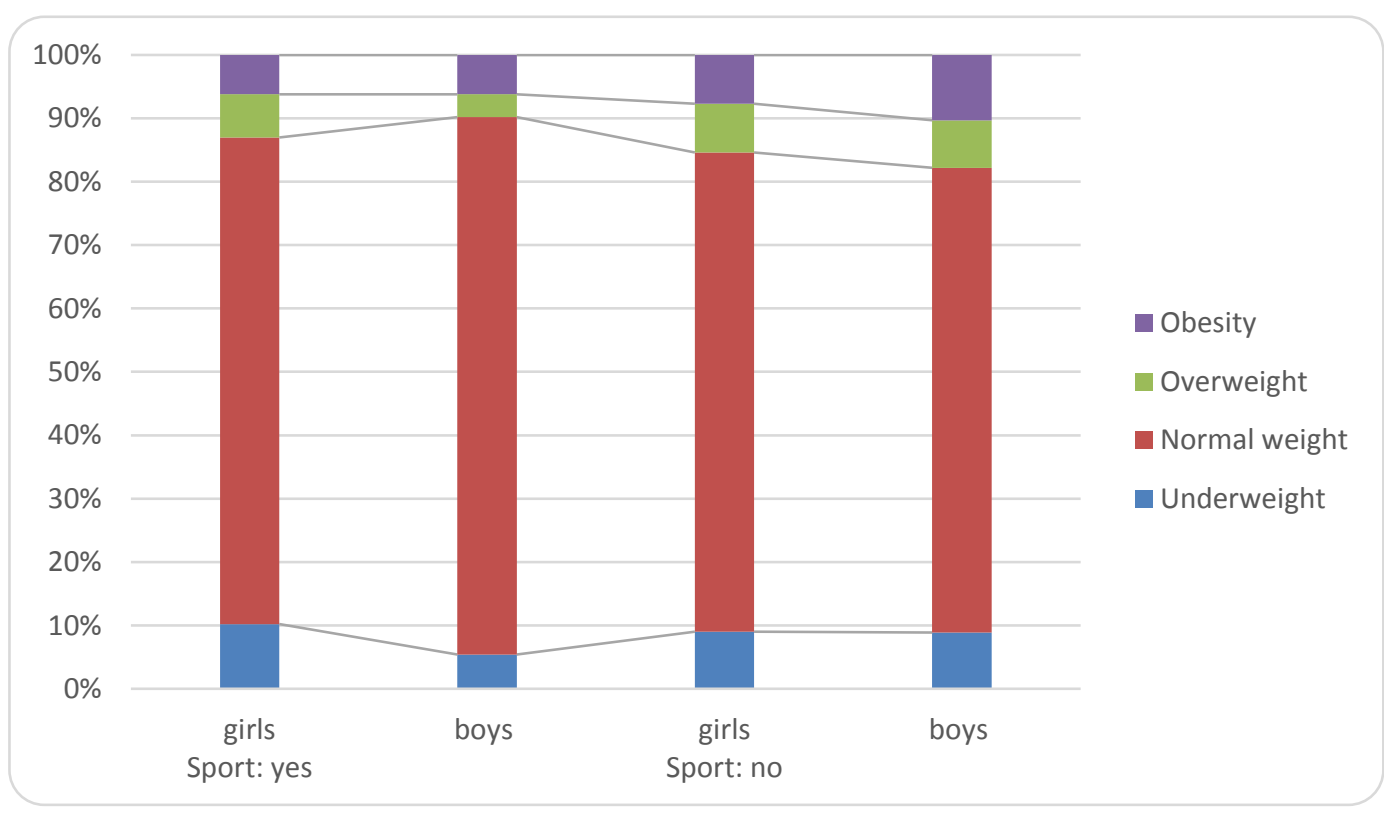

Figure 1 Graphical form of the relative representation of underweight, normal weight, overweight, and obese children in the groups of physically active girls and boys and physically inactive girls and boys. 


\subsection{Comparison of motion prerequisites}

By comparing the level of motion prerequisites of a group of physically active and physically inactive children, we found interesting facts. When comparing the results of individual tests of the DMT 6-18 battery, we found that the differences between physically active and physically inactive children are significant at some tests at the level of statistical significance $a \geq$ 0.05. The exception is the balancing backwards test. The difference in the number of steps of each of the attempts on individual balance beam widths is not significant between physically active and physically inactive children. We found moderate substantive significance in both attempts of the standing long jump and six-minute run tests. Substantive significance was calculated in both attempts of the 20-metre sprint, jumping sideways, push-ups, and sit-ups tests.

\section{Discussion}

After evaluating somatic characteristics, we noticed that in the group of physically active boys, the number of children with higher weight is low, and the most children show normal weight (84.7\%). On the contrary, in the group of physically inactive boys, a relatively high percentage of children with higher weight can be found (17.8\%).
These values are not applicable in an international comparison as all BMI values are related to the reference values of the 90th, 97th, and 10th percentiles valid for the Czech population [26].

The research sample consisted of 332 girls and 421 boys. Of this number, 176 girls (53\% of all girls) and 275 boys ( $65.3 \%$ of all boys) were physically active.

From figure 2, we can see that the proportion of physically active boys is higher than the proportion of physically active girls. This imbalance can be caused by many reasons. Physical training hobby groups and sporting activities offered in sports centres are intended to boys and girls. In the age range of 6 to 7 years, the parents' opinion and their relationship to physical activities is relatively important. Among parents of the pupils from our sample, it is believed that sporting activities performed in leisure time are more important to boys than to girls. It is also possible that boys require the inclusion in sporting activities more often than girls. With regard to the fact that Graph 2 shows a higher proportion of physically active boys in our research sample, we compared the individual groups of physically active and physically inactive girls and boys also in the case of motion assumptions.

Table 4 Results of the t-test and substantive significance of two independent samples; groups of physically active and physically inactive pupils of the first grades of Pilsen primary schools.

\begin{tabular}{|l|l|l|l|}
\hline & t-test value & p value & d value \\
\hline SPRINT_1 & -6.50 & $0 *$ & $0.46^{* * *}$ \\
\hline SPRINT_2 & -6.39 & $0 *$ & $0.48^{* * *}$ \\
\hline BAL_SUM & 1.65 & 0.10 & 0.12 \\
\hline JUMP_1 & $\mathbf{5 . 1 1}$ & $0 *$ & $0.37 * * *$ \\
\hline JUMP_2 & $\mathbf{5 . 2 9}$ & $0 *$ & $0.39 * * *$ \\
\hline STAND_REACH & $\mathbf{2 . 1 9}$ & $0.03 *$ & 0.16 \\
\hline PUSH_UP & $\mathbf{2 . 7 4}$ & $0.01 *$ & $0.2 * * *$ \\
\hline SIT_UPS & 4.89 & $0 *$ & $0.36^{* * *}$ \\
\hline LONG_J_1 & $\mathbf{7 . 7 2}$ & $0 *$ & $\mathbf{0 . 5 7} * *$ \\
\hline LONG_J_2 & $\mathbf{8 . 1 6}$ & $0 *$ & $\mathbf{0 . 5 4} * *$ \\
\hline 6-MIN RUN & $\mathbf{7 . 1 0}$ & $0 *$ & $\mathbf{0 . 5 1} * *$ \\
\hline
\end{tabular}

$* \mathbf{p} \geq \mathbf{a} \geq 0.05$

$* * 0.5 \geq \mathrm{d} \geq 0.8$ mean substantive significance

$* * * 0.2 \geq d \geq 0.5$ small substantive significance 


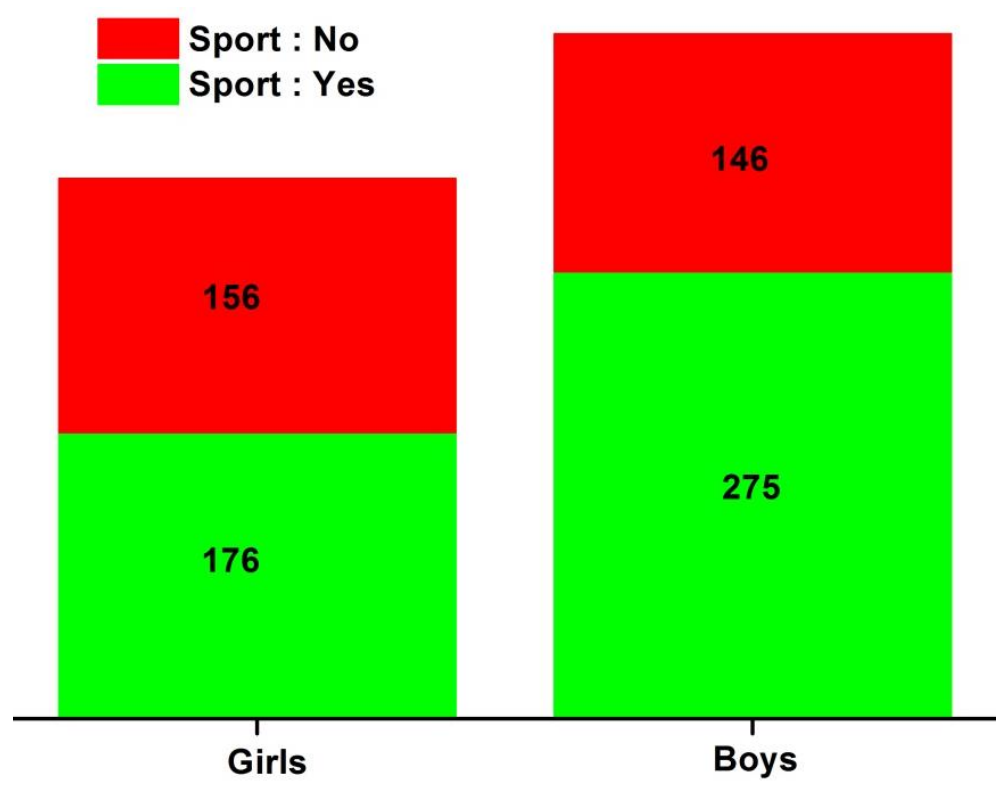

Figure 2 Bar graph showing the proportion of physically active and physically inactive girls and boys.

Table 5 Comparison of physically active and physically inactive girls and boys in the individual motor tests of the DMT6-18 battery

\begin{tabular}{|c|c|c|c|c|c|c|}
\hline & \multicolumn{3}{|c|}{ girls } & \multicolumn{3}{c|}{ boys } \\
\cline { 2 - 7 } & $\begin{array}{c}\text { t-test } \\
\text { value }\end{array}$ & $\mathbf{p}$ value & $\mathbf{d}$ value & $\begin{array}{c}\text { t-test } \\
\text { value }\end{array}$ & p value & $\begin{array}{c}\text { d } \\
\text { value }\end{array}$ \\
\hline 20-METRE-SPRINT_1 & $\mathbf{- 3 , 0 8}$ & $\mathbf{0} *$ & $0,34 * * *$ & $\mathbf{- 5 , 1 3}$ & $\mathbf{0} *$ & $\mathbf{0 , 5 1} * *$ \\
\hline 20-METRE-SPRINT_2 & $\mathbf{- 3 , 2 6}$ & $\mathbf{0} *$ & $0,36 * * *$ & $\mathbf{- 4 , 7 6}$ & $\mathbf{0} *$ & $0,47 * * *$ \\
\hline BAL_SUM & 1,91 & 0,06 & $0,22 * * *$ & 1,22 & 0,22 & 0,13 \\
\hline JUMPING SIDEWAYS_1 & $\mathbf{2 , 3 2}$ & $\mathbf{0 , 0 2} *$ & $0,25 * * *$ & $\mathbf{4 , 6 4}$ & $\mathbf{0} *$ & $0,47 * * *$ \\
\hline JUMPING SIDEWAYS_2 & $\mathbf{3 , 3 7}$ & $\mathbf{0} *$ & $0,37 * * *$ & $\mathbf{4 , 1 6}$ & $\mathbf{0} *$ & $0,42^{* * *}$ \\
\hline FORWARD BEND & $\mathbf{2 , 6 2}$ & $\mathbf{0 , 0 1} *$ & $0,31^{* * *}$ & 1,35 & 0,18 & 0,15 \\
\hline PUSH_UP & $\mathbf{2 , 4 9}$ & $\mathbf{0 , 0 1} *$ & $0,27 * * *$ & 1,34 & 0,18 & 0,14 \\
\hline SIT_UPS & $\mathbf{3 , 5 5}$ & $\mathbf{0} *$ & $0,39 * * *$ & $\mathbf{2 , 8 8}$ & $\mathbf{0} *$ & $0,3 * * *$ \\
\hline LONG_JUMP_1 & $\mathbf{3 , 2 6}$ & $\mathbf{0} *$ & $0,35 * * *$ & $\mathbf{6 , 8 6}$ & $\mathbf{0} *$ & $\mathbf{0 , 6 7} * *$ \\
\hline LONG_JUMP_2 & $\mathbf{3 , 9 5}$ & $\mathbf{0} *$ & $0,4 * * *$ & $\mathbf{6 , 8 1}$ & $\mathbf{0} *$ & $\mathbf{0 , 6 4 * *}$ \\
\hline RUN_6MIN & $\mathbf{2 , 6 8}$ & $\mathbf{0 , 0 1 *}$ & $0,29 * * *$ & $\mathbf{6 , 2 2}$ & $\mathbf{0} *$ & $\mathbf{0 , 6 1} * *$ \\
\hline
\end{tabular}

$* \mathbf{p} \geq \mathbf{a} \geq 0.05$

$* * 0.5 \geq \mathrm{d} \geq 0.8$ mean substantive significance

$* * * 0.2 \geq \mathrm{d} \geq 0.5$ small substantive significance

We took this step primarily in order to avoid any possible bias of our research.

Differences between the boys and girls in the individual tests within the sample as a whole appeared to be significant in the balancing backwards and stand and reach tests, in which the girls achieved better results. In the push-ups and six-minute run tests, the boys achieved significantly better results.
We guess that these results fully correspond to the described age-specificities in motor manifestations of younger school age children. In our more detailed analysis, we revealed several other differences.

Table 5 shows that the results of comparing the group of physically active and inactive girls and boys separately are similar. In the physically active and inactive girls, statistically significant differences were 
found in all tests except the balancing backwards test. In all our tests, substantive significance was determined as small. In physically active and inactive boys, statistically significant differences were found in the 20-metre sprint, jumping sideways, sit-ups, standing long jump, and six-minute run tests. The mean substantive significance of the difference between physically active and inactive boys was manifested in the 20-metre sprint, standing long jump, and six-minute run tests. It is interested that there was no difference between the physically active and inactive boys in the modified push-up test. We can assume that for this age group, this test was quite complicated from the viewpoint of its proper performance, and the boys, in their effort to carry out this exercise as quickly as possible, failed to follow the correct parameters of the exercise, therefore, incorrectly performed exercise was not counted

\section{Conclusions}

In conclusion, we can state that statistically significant differences were found among the children already in the age range of 6-7 years, who are engaged in any organised physical activities in their leisure time, and children who spend their leisure time rather inactively. This trend was also objectively supported. The results of substantive significance, calculated as low to mean, draw our attention to the fact that other factors also play a role in pupils' motor performance at this early school age. The mental development of children is primarily considered as one of the decisive factors. In addition to movement skills, performance of some tests requires also concentration and motion memory. It is evident that physical education at schools is often the only physical activity for many children. Therefore, emphasis should be placed on high qualification and interest of school teachers at the first level of primary schools. We recommend including physical activities of younger school-age children at schools as often as possible. We also recommend using the option to include a third physical education lesson, and to include recreation and movement breaks on a daily basis. In many subjects of the educational plan, it is possible to use the kinesthetic style of teaching, or to teach children outdoors in motion. Another way how to improve the movement regimen of younger school children is to expand the offer of physical training hobby groups at after-school care centres, or to include physical activities directly into after-school care centre programmes.

\section{References}

[1] Consultation document to guide development of a WHO Global Strategy for Diet, Physical Activity and Health, WHO, (2003).

http://www.who.int/dietphysicalactivity/en

[2] V. Mužík., P. Vodáková, (2001) Sonda do školní pohybové aktivity dětí mladšího školního věku, in E. Rehulka (ed.), Škola a zdraví 21, výchova ke zdraví: podněty ke vzdělávacím oblastem. Brno: Masarykova univerzita.

[3] E. Sigmund, M. De Ste Croix, L. Miklánková, K. Frömel, Physical activity patterns of kindergarten children in comparison to teenagers and young adults, European Journal of Public Health, 17 (2007) 646-651.

\section{https://doi.org/10.1093/eurpub/ckm033}

[4] E. Sigmund, L. Miklánková, J. Mitáš, D. Sigmundová, K. Frömel, Provází nástup dětí do 1. tř́dy základní školy výrazný pokles jejich pohybové aktivity?, Medicina Sportiva Bohemica \& Slovaca, 16(2) (2007) 78-84.

[5] P. Valach, K. Frömel, L. Jakubec, D. Benešová, V. Salcman, Pohybová aktivita a sportovní preference západočeských adolescentů, Tělesná kultura, 40(1) (2017) 45-53.

\section{https://doi.org/10.5507/tk.2017.003}

[6] D. Benešová, P. Valach, Development of somatic characteristics among younger school-age children with respect to their physical activities. In ICERI2019 Proceedings, (2019) Seville, Spain.

[7] K. Ginsburg, The Importance of play in promoting healthy child development and maintaining strong parent-child bonds, Journal Pediatrics, 119 (2007) 182-191.

https://doi.org/10.1542/peds.2006-2697

[8] P. Valach, D. Benešová, V. Salcman, H. Schulz, (2016) Děti $v$ pohybu: výzkumná studie $v$ rámci mezinárodního projektu Comenius, Netzwerk Soziale Dienste und Ökologische Bildung, Köln, Germany.

[9] C. Tsioufis, S. Kyvelou, D. Tsiachris, P. Tolis, G. Hararis, N. Koufakis, T. Psaltopoulou, D. Panagiotakos, P. Kokkinos, C. Stefanadis, Relation between physical activity and blood pressure levels in young Greek adolescents: The Leontio Lyceum Study, European Journal of Public Health, 21(1) (2011) 63-68.

\section{https://doi.org/10.1093/eurpub/ckq006}

[10] J. Mitáš, K. Frömel, P. Valach, A. Suchomel, M. Vorlíček, D. Groffik, Secular trends in the achievement of physical activity guidelines: indicator of sustainability of healthy lifestyle in Czech adolescents, Sustainability, 12(12) (2020) 1-14. https://doi.org/10.3390/su12125183 
[11] E. Kuntsche, U. Ravens-Sieberer, Monitoring adolescent health behaviours and social determinants cross-nationally over more than a decade: introducing the Health Behaviour in School-aged Children (HBSC) study supplement on trends, European Journal of Public Health, 25(2) (2015) 1-3.

\section{https://doi.org/10.1093/eurpub/ckv009}

[12] L. Gagen, N. Getchell, Using 'Constraints' to Design Developmentally Appropriate Movement Activities for Early Childhood Education, Early Childhood Education Journal, 34(3) (2006) 227232. https://doi.org/10.1007/s10643-006-0135-6

[13] H. G. Williams, K. A. Pfeiffer, J. R. O'Neill, M. Dowda, K. L. McIver, W. H. Brown, R. R. Pate, Motor skill performance and physical activity in preschool children, Obesity, 16(6) (2008) 14211426. https://doi.org/10.1038/oby.2008.214

[14] A. H. N. Ré, Crescimento, maturação e desenvolvimento na infância e adolescência: implicações para o esporte, Motricidade, 7(3) (2011) 55-67. https://doi.org/10.6063/motricidade.7(3).103

[15] D. Benešová, U. Lange, J. Oelze, V. Salcman, H. Schulz, S. Schuster, P. Valach, (2014) Přeshraniční srovnávací analýza motorických schopností dětí mladšího školního věku - pilotní studie, Universitätsverlag, Chemnitz, Germany.

[16] I. Galvão, Expressividade e emoção: ampliando o olhar sobre as interações sociais, Revista Paulista de Educação Física, 4 (2001) 15-31. https://doi.org/10.11606/issn.25945904.rpef.2001.139590

[17] R. J. Krebs, (1995) Urie Bronfenbrenner e a ecologia do desenvolvimento humano, Casa Editoral, Santa Maria.

[18] D. BENEŠOVÁ, V. SALCMAN, P. VALACH, Porovnání pohybových předpokladů dětí $\mathrm{s}$ odlišným sociálním statusem, Studia Kinanthropologica, 17(3) (2016) 195-201.

[19] K. Libertus, D. A. Violi, Sit to talk: relation between motor skills and language development in Infancy, Frontiers in Psychology, 7(75) (2016) 475.

\section{https://doi.org/10.3389/fpsyg.2016.00475}

[20] K. Frömel, D. Groffik, J. Mitášs, J. Dygrýn, P. Valach, M. Šafáŕ, Active travel of Czech and Polish adolescents in relation to their well-being: support for physical activity and health, International Journal of Environmental Research and Public Health, 17(6) (2020) 1-13. https://doi.org/10.3390/ijerph17062001

[21] K. Bös, L. Schlenker, D. Büsch, L. Lämmle, H. Müller, J. Oberger, I. Seidel, S. Tittlbach, (2009) Deutsche Motorik-Test 6-18 (DMT 6-18), Czwalina, Hamburg, Germany.

https://doi.org/10.1007/978-3-531-94026-7 21
[22] V. Svatoň, J. Tupý, (1997) Program zdravotně orientované zdatnosti, NS Svoboda, Praha, Czech Republic.

[23] P. Valach, J. Vašíčková, K. Frömel, L. Jakubec, F. Chmelík, Z. Svozil, Is academic achievement reflected in the level of physical activity among adolescents?, Journal of Physical Education and Sport, 20(1) (2020) 186-195.

\section{https://doi.org/10.7752/jpes.2020.01025}

[24] J. Öelze, N. Richter, H. Schulz, Familiäre Bewegungsafinität und motorische Leistungsfähigkeit im Einschulungsalter, Deutsche Zeitschrift für Sportmedizin, 64(7-8) (2011) 228.

[25] I. Moor, M. Richter, U. Ravens-Sieberer, Trends in social inequalities in adolescent health complaints from 1994 to 2010 in Europe, North America and Israel: The HBSC study, European Journal of Public Health, 25 (2) (2015) 57-60.

https://doi.org/10.1093/eurpub/ckv028

[26] Změny tělesných proporcí, prevalence nadměrné hmotnosti a obesity, National Institute of Public Health

(2005), www.szu.cz/uploads/documents/obi/CAV/6.CAV 3 Zmeny telesnych proporc.pdf

[27] P. Mareš, L. Rabušic, P. Soukup, (2015) Analýza sociálněvědních dat $v$ SPSS, Masarykova univerzita, Brno, Czech Republic.

[28] R. T. Thomas, K. N. Nelson, S. J. Silverman, (2003) Research methods in physical activity, Human Kinetic, Champaign, Illinois.

\section{Acknowledgement}

NIL

\section{Funding}

This work was supported by West Bohemia University under grant No. SGS-2019-011.

\section{Authors Contribution}

Study conceptualization, methodology and Manuscript preparation; K. Svatora, Manuscript preparation, review and editing; P. Spottova, Manuscript preparation, review and editing; T. Fajfrlikova. All authors have read and approved the manuscript.

\section{Conflict of interest}

The authors declare that they have no actual or potential conflict of interest, including financial, personal or other relationships with people or organizations that could have inappropriately influenced this work.

Informed consent

All participants gave written informed consent to participate in this study.

\section{About The License}

(C) The author(s) 2020. The text of this article is open access and licensed under a Creative Commons Attribution 4.0 International License 